\title{
Cold Storage Influences Internal Characteristics of Nectarines during Ripening
}

\author{
L.J. von Mollendorff ${ }^{1}$ \\ Stellenbosch Institute for Fruit Technology, Private Bag X5013, \\ Stellenbosch 7599, South Africa
}

\author{
G. Jacobs ${ }^{2}$ \\ Department of Horticulture, University of Stellenbosch, 7600, \\ South Africa
}

\section{O.T. de Villiers ${ }^{2}$ \\ Department of Botany, University of Stellenbosch, 7600, South Africa}

Additional index words. Prunus persica, browning, cold injury, extractable juice, conductivity, woolliness

Abstract. 'Flavortop' nectarines [Prunus persica (L.) Batsch] were stored at -0.5C or $3 \mathrm{C}$ for $0,1,2,3$, or 4 weeks, after which the fruit was ripened at $15 \mathrm{C}$. After ripening, fruit samples were tested daily or every second day for extractable juice, internal conductivity, and woolliness. The change in the percentage of extractable juice during ripening differed very little among the five storage periods. A rapid increase in internal conductivity occurred during ripening in fruit with or without cold storage, but the onset of the increase was advanced with longer cold-storage periods. No woolliness developed in fruit not placed in cold storage or in fruit cold-stored for 1 or 2 weeks at - $0.5 \mathrm{C}$ or $3 \mathrm{C}$. Woolliness only developed during ripening of fruit cold-stored for 3 or 4 weeks at $-\mathbf{0 . 5 C}$ or $3 \mathrm{C}$. Incidence of woolliness increased to high levels during ripening and decreased thereafter to no woolly fruit by the 11th day. The lowest values for extractable juice coincided with the highest incidence of woolly fruit. Fruit stored for 4 weeks took longer to pass the woolliness stage. At the end of the ripening. period, cold-stored fruit were similar in appearance and juiciness to those ripened without cold storage. Nectarines stored at $3 \mathrm{C}$ generally developed woolliness earlier, had a lower incidence of woolliness, and took longer to overcome the problem than fruit stored at $\mathbf{- 0 . 5 C}$. Incidence of browning of the mesocarp tissue was greater at $3 \mathrm{C}$ than at $-0.5 \mathrm{C}$.

Woolliness in peaches and nectarines is a physiological abnormality that develops during ripening after prolonged cold storage (De Haan, 1957; Morris, 1982; O’Reilly, 1947). Woolliness symptoms are associated with a dry, mealy texture that is accompanied by a loss of flavor and brightness of color; also, no juice can be squeezed from the fruit (Boyes, 1952). Peach and nectarine cultivars differ in their susceptibility to woolliness (Eksteen, 1984; Mitchell et al., 1977; Von Mollendorff, 1987). Storage at 3C causes a higher incidence of woolliness and browning than storage at 0.5C (Anderson, 1979; Boyes, 1952; Bramlage, 1982; Guelfat-Reich and Ben-Arie, 1966). According to Ben-Arie and Sonego (1980), woolliness results from the

Received for publication 19 Sept. 1991. This paper is based on part of a $\mathrm{PhD}$ dissertation accepted at the Univ. of Stellenbosch, Stellenbosch. We are grateful for the technical assistance from J. Jacobs, I. Westraad, R. Rhode, and W. Fortuin. The cost of publishing this paper was defrayed in part by the payment of page charges. Under postal regulations, this paper therefore must be hereby marked advertisement solely to indicate this fact.

${ }^{1}$ Research Scientist.

${ }^{2}$ Professor. abnormal metabolism of pectic substances. The pectates form a gel in the presence of water, resulting in a loss of expressible juice and the development of woolliness. The degree of woolliness in a midseason nectarine cultivar changed drastically during ripening after a cold-storage period of 4 weeks (Von Mollendorff et al., 1989). As ripening progressed, the incidence of woolly fruit first increased to a maximum, then decreased. Maximum incidence of woolliness was associated with minimum juice extraction. In woolly peaches, the viscosity of soluble pectin was higher than in nonwoolly peaches (Von Mollendorff and De Villiers, 1988). Furmanski and Buescher (1979) noted an increase in electrolyte leakage and internal conductivity upon ripening of peaches stored 1 or 2 weeks at $1 \mathrm{C}$.

Since cold storage temperatures and periods affect the development of woolliness and membrane permeability in peaches, we investigated the effect of storage duration and temperature on the development of woolliness, changes in extractable juice and internal electrical conductivity, and on browning of tissue of nectarines during ripening.

'Flavortop' nectarines of uniform size (66$70 \mathrm{~mm}$ ) were obtained from a commercial farm in the Elgin area, South Africa. Average fruit firmness was $107 \mathrm{~N} \pm 11 \mathrm{~N}$, measured with an Effegi penetrometer (Effegi, Italy) with an 11-mm probe. The fruit were randomly divided into 10 groups of 600 fruit each. Five groups each were stored at -0.5 or $3 \mathrm{C}$ for $0,1,2,3$, or 4 weeks. After each storage period, fruit was ripened at $15 \pm$ $0.5 \mathrm{C}$. Samples of 60 fruit were tested daily or every 2 nd day for percent extractable juice, internal electrical conductivity, and incidence of woolliness. On each examination date, three replicates of 20 fruit were used to determine extractable juice by homogenizing $200 \mathrm{~g}$ of tissue for $60 \mathrm{sec}$ in a Waring blender. The suspension was allowed to stand for $15 \mathrm{~min}$ before centrifugation for $10 \mathrm{~min}$ at $1000 \times g$. The clear decanted liquid was weighed and expressed as a percentage of the fresh fruit weight.

Internal conductivity was determined with a conductivity bridge connected to a Consort C925k combination $\mathrm{pH} / \mathrm{EC} /{ }^{\circ} \mathrm{C}$ meter (Consort, The Netherlands). The electrodes consisted of two stainless steel needles held 7
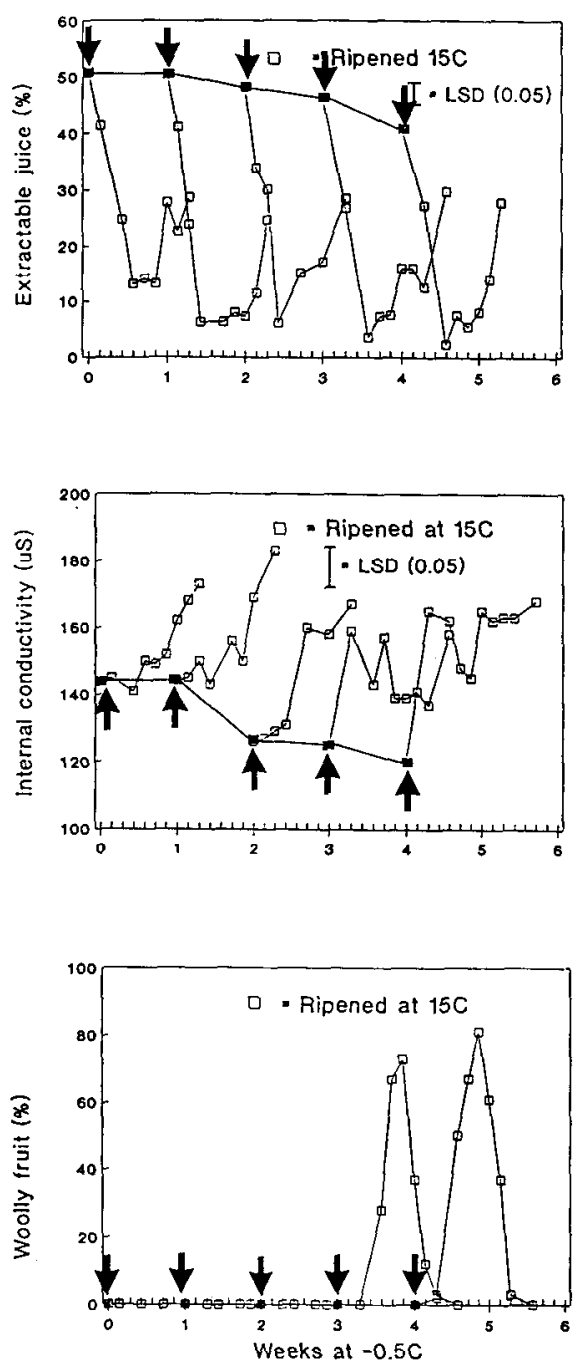

Fig. 1. Extractable juice (top), internal conductivity (center), and incidence of woolliness (bottom) of 'Flavortop' nectarines during storage at $-0.5 \mathrm{C}(\boldsymbol{W})$ and after transfer to $15 \mathrm{C}$ ( $\square)$. Arrows indicate the time when samples were transferred from $-0.5 \mathrm{C}$ to $15 \mathrm{C}$. 

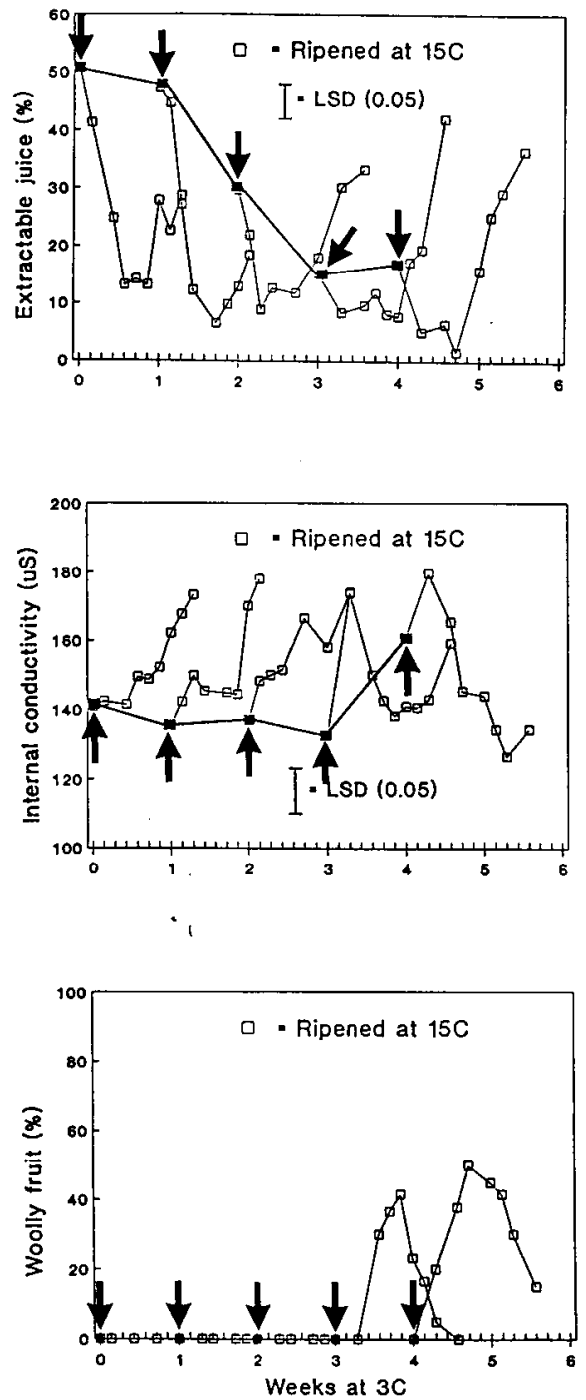

Fig. 2. Extractable juice (top), internal conductivity (center), and incidence of woolliness (bottom) of 'Flavortop' nectarines during storage at 3C ( $\square$ ) and after transfer to $15 \mathrm{C}(\square)$ Arrows indicate the time when samples were transferred from $3 \mathrm{C}$ to $15 \mathrm{C}$.

$\mathrm{mm}$ apart in a perspex stopper (Weaver and Jackson, 1966). The needles were pressed to a depth of $5 \mathrm{~mm}$ into the fruit. All measurements were taken at the equatorial diameter and the mean of 60 fruit was recorded.

Woolliness and browning of nectarines was visually assessed on each of the 60 fruit mentioned above. Fruit was cut into halves and squeezed. If the juice appeared thick and did not flow freely, the fruit was considered woolly. Browning was recorded as present if mesocarp tissue of the fruit was discolored.

Experiments were laid out in a complete randomized design; analysis of variance was performed and Student's least significant difference (LSD) was calculated to compare treatment means (Snedecor and Cochran, 1980). No statistical analysis was performed on the subjective evaluation of the percentage of woolly fruit.

'Flavortop' nectarines had a high extractable juice content (50\%) at harvest (Fig. 1, top and 2, top). When ripened at $15 \mathrm{C} \mathrm{im-}$ mediately after harvest, the juice content decreased to low levels (10\% to $15 \%$ ) on the 4th and 6th day of ripening, after which it increased to $\approx 30 \%$. During low-temperature storage, the juice content decreased more rapidly and to lower levels at 3C (Fig. 2, top) than at $-0.5 \mathrm{C}$ (Fig. 1, top). The change in the extractable juice content during ripening of cold-stored fruit was similar to that of noncold-stored fruit, irrespective of the period of storage. However, the minimum values for fruit stored at $-0.5 \mathrm{C}$ and ripened at $15 \mathrm{C}$ decreased with longer cold-storage periods compared with those of fruit not coldstored.

The internal conductivity of noncold-stored nectarines increased gradually during the first 6 days of ripening (Fig. 1, center). In contrast, the internal conductivity in fruit stored for 1 week at $-0.5 \mathrm{C}$ (Fig. 1, center) or $3 \mathrm{C}$ (Fig. 2, center) either remained unchanged, fluctuated, or increased slightly during the first 6 days of ripening but increased rapidly with further ripening. After storage for 2 weeks, a similar tendency was observed, but the internal conductivity increased rapidly after 4 days of ripening. In fruit stored for 3 or 4 weeks at $-0.5 \mathrm{C}$ or 3 weeks at $3 \mathrm{C}$, the internal conductivity was high on the first day of ripening. In fruit stored at $3 \mathrm{C}$ for 4 weeks, the internal conductivity started to increase during cold storage, and this increase continued during ripening (Fig. 2, center). Internal conductivity remained high or decreased during further ripening, with a tendency to increase during the final stages of ripening.

No woolliness was observed on removal of fruit from cold storage, irrespective of coldstorage temperature or period. Nectarines only became woolly during ripening after storage of 3 or 4 weeks at -0.5 and $3 \mathrm{C}$ (Figs. 1, bottom and 2, bottom). After storage at $-0.5 \mathrm{C}$ for 3 or 4 weeks, the incidence of woolly fruit increased rapidly from the 2 nd day of ripening to reach high levels $(73 \%$ and $80 \%$, respectively) on the 6th day, The incidence of woolliness decreased as ripening progressed and was zero after the 11th day. These fruit were similar in appearance and juiciness to those ripened immediately after harvest (data not shown). Nectarines stored at 3C generally developed woolliness quicker after 4 weeks of cold storage, had a lower incidence of woolly fruit. and took longer to progress through the woolliness stage than fruit stored at $-0.5 \mathrm{C}$.

In nectarines stored at $3 \mathrm{C}$ for 3 weeks, browning of the mesocarp tissue was observed in $18 \%$ of the fruit from the 6th day of ripening. After 4 weeks at 3C, $50 \%$ of the fruit developed browning from the 2 nd day of ripening. In contrast, none of the fruit stored at $-0.5 \mathrm{C}$ developed browning at any time.

Ben-Arie and Lavee (1971) postulated that pectic substances can form gels with water. Gelling of the water by soluble pectins possibly explains the reduction in the extractable juice during ripening of noncold-stored and cold-stored fruit. The increase of the extractable juice content after the 6th day of rip- ening was probably due to prolonged polygalacturonase (PG) activity, yielding pectin of very low molecular mass (Chang and Smith, 1973; Pressey et al., 1971) which does not gel as readily (Doesburg, 1965). The minimum values for extractable juice gradually decreased with increased storage duration. The period of cold storage might influence pectic enzyme activity. Ben-Arie and Sonego (1980) indicated that pectinmethylesterase demethylates pectins and inhibits PG during 4 weeks of low-temperature storage, resulting in a low-methoxyl pectin of high molecular mass that holds water in a gel.

Furmanski and Buescher (1979) found that internal conductivity of fruit increased upon ripening after 1 and 2 weeks of cold storage, probably an indication of loss of cell membrane integrity. Cell fluids and solutes can leak through such membranes and accumulate in the intercellular spaces, thus increasing conductivity (Buescher, 1974; Christianson et al., 1970; Lyons, 1973). Internal conductivity will also increase if ions and other electrolytes that bind to sites in the pectin molecules are released (Furmanski and Buescher, 1979). Our results show that although a rapid increase in internal conductivity occurred in both noncold-stored and cold-stored fruit during ripening, the onset of the increase was advanced by longer coldstorage periods. In noncold-stored fruit, the rapid increase in internal conductivity occurred after a critical point during ripening when fruit was in an advanced stage of ripeness and contained relatively large amounts of extractable juice. At that stage, pectin breakdown had progressed to a point where molecular mass was apparently too small for the pectins to gel, as indicated by the relatively large amounts of extractable juice in these fruit.

No woolliness developed in fruit not stored or cold-stored for 1 or 2 weeks at either storage temperature. During ripening of these fruit, the pectins possessed gelling properties (low extractable juice values) and internal conductivity was low. Membranes were, therefore, apparently still intact. When fruit were squeezed during the test for woolliness, the fruit appeared juicy and nonwoolly. Internal conductivity increased during advanced ripening, and membranes integrity was affected, while pectin breakdown must have proceeded to a stage where its ability to bind free water (high extractable juice values) was greatly reduced. When the woolliness test was performed on these fruit, they also appeared juicy and not woolly. Nectarines only became woolly during ripening after 3 or 4 weeks of storage at -0.5 and $3 \mathrm{C}$. Internal conductivity was high when cold-stored fruit was transferred to conditions favorable for ripening and when the amount of extractable juice was low. If an increase in internal conductivity is associated with enhanced membrane permeability (Lyons, 1973), then increased leakage of cell fluids and solutes occurs through the cell membrane into the intercellular spaces to form gels with high molecular mass pectins (Von Mollendorff et 
al., 1992). As ripening progressed, woolliness disappeared when pectins lost their gelling properties due to breakdown, resulting in increased levels of extractable juice.

The reduction in internal conductivity after the initial increase during ripening of fruit cold-stored for 3 or 4 weeks is possibly the result of electrolytes being bound to high molecular mass pectins during the occurrence of woolliness (Furmanski and Buescher, 1979).

Kader and Chordas (1984) found that the browning potential of cold-stored peaches depends on the total amount of phenolic compounds present in fruit and the level of activity of polyphenol oxidase (PPO). Normally, phenolic compounds are physically separated from PPO in intact fruit, but when fruit is damaged (e.g., bruising and possibly cold storage), substrate and enzyme are accessible to each other and chemical reactions lead to browning. PPO is highly active in peaches at 3C (Jen and Kahler, 1974), and this may explain why more browning occurred at $3 \mathrm{C}$ than at $-0.5 \mathrm{C}$. Temperatures such as - 0.5C may inhibit PPO activity and, therefore, oxidation of phenols during ripening.

\section{Literature Cited}

Anderson, R.E. 1979. The influence of storage temperature and warming during storage on peaches and nectarine fruit quality. J. Amer. Soc. Hort. Sci. 104:459-461.

Ben-Arie, R. and S. Lavee. 1971. Pectic changes occurring in Elberta peaches suffering from woolly breakdown. Phytochemistry 10:531-538.

Ben-Arie, R. and L. Sonego. 1980. Pectolytic enzyme activity involved in woolly breakdown of stored peaches. Phytochemistry 18:2553-2555.

Boyes, W.W. 1952. Woolliness in cold storage peaches. Deciduous Fruit Grower 2:13-17.

Bramlage, W.J. 1982. Chilling injuries of crops of temperate origin. HortScience 17:165-168.

Buescher, R.W. 1974. Quality changes in tomatoes as affected by low temperature storage of unripe fruit. Ark. Farm Res: 23:11.

Chang. Y.S. and C.J.B. Smith. 1973. Characteristics of pectins isolated from soft and firm fleshed peach varieties. J. Food Sci. 38:646648.

Christianson, M.N., H.R. Carns, and D.J. Slyter. 1970. Stimulation of solute loss from radicles of Gossypium hirsutum L. by chilling, anaerobiosis and low pH. Plant Physiol. 46:53-56.

De Haan, I. 1957. Pectin conversions in peaches during cold storage. S. Afr. Ind. Chem. 11:2634.

Doesburg, J.J. 1965. Pectic substances in fresh and preserved fruits and vegetables. H. Veenman and N.V. Zonen, Wageningen, The Netherlands.

Eksteen, G. 1984. A summary of recent results on woolliness in local nectarines. Deciduous Fruit Grower 34:389-392.

Furmanski, R.J. and R.W. Buescher. 1979. Influence of chilling on electrolyte leakage and internal conductivity of peach fruits. HortScience 14:167-168.

Guelfat-Reich, S. and R. Ben-Arie. 1966. Effect of delayed storage and stage of maturity at harvest on the keeping quality of peaches in Israel. Israel J. Apr. Res. 18:163-170.

Jen, J.J. and K.R. Kahler. 1974. Characterization of polyphenol oxidase in peaches grown in the Southeast. HortScience 9:590-591.

Kader, K.R. and A. Chordas. 1984. Evaluating the browning potential of peaches. Calif. Agr. 38:14-15.

Lyons, J.M. 1973. Chilling injury in plants. Annu. Rev. Plant Physiol. 24:445-466.

Mitchell, F.G., G. Mayer, and R.H. Breede. 1977. Postharvest performance of shipping stone fruit. 1976 tests. Spec. Project Rpt., Dept. of Pomology, Univ. of California, Davis.

Morris, L.L. 1982. Chilling injury of horticultural crops: An overview. HortScience 17:161-162.

O'Reilly, H.J. 1947. Peach storage in modified atmospheres. Proc. Amer. Soc. Hort. Sci. 49:99106

Pressey, R., D.M. Hinton, and J.K. Avants. 1971. Development of polygalacturonase activity and solubilization of pectin in peaches during ripening. J. Food Sci. 36:1070-1073.

Snedecor. G.W. and W.G. Cochran. 1980. Statistical methods. 7th ed. Iowa State Univ. Press, Ames.
Von Mollendorff, L.J. 1987. Woolliness in peaches and nectarines: A review. 1. Maturity and external factors. Tuinbouwetenskap/Hort. Sci. 5:13.

Von Mollendorff, L.J. and O.T. De Villiers. 1988. Role of pectolytic enzymes in the development of woolliness in peaches. J. Hort. Sci. 83:5358.

Von Mollendorff, L.J., O.T. De Villiers, and G. Jacobs. 1989. Effect of time of examination and ripening temperature on the degree of woolliness in nectarines. J. Hort. Sci. 64:443-447.

Von Mollendorff, L.J., O.T. De Villiers, and G. Jacobs. 1992. An anatomical and histological study of changes in mesocarp tissue during storage and ripening of 'Flavortop' nectarines. J. S. Afr. Soc. Hort. Sci. 2:14-18

Weaver, G.M. and H.O. Jackson. 1966. Electrical impedance, an objective index of maturity in peaches. Can. J. Plant Sci. 46:323-326. 